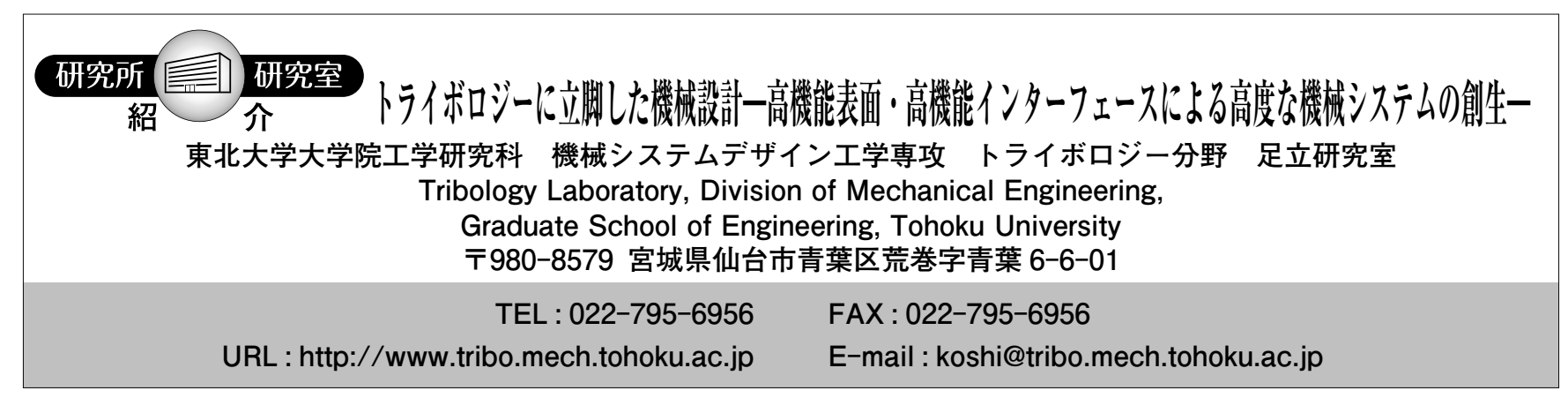

\section{1. 研究室の沿革と概要}

東北大学機械系トライボロジー分野の起点は,「トライ ボロジー」を日本で初めて講座名として設立された 1987 年に遡ります, 以来, トライボロジー講座を牽引された加 藤康司教授（現日本大学工学部教授）の定年退職ならびに 教授, 准教授独立研究室制の導入に伴い 2007 年 4 月より 東北大学機械系トライボロジー分野は, 現在の単独研究室 として新たにスタートいたしました。

現在，研究室では「ものつくり」を意識する姿勢とトラ イボロジーの科学技術を基盤にした「安全安心かつ高度な 機械機器」を追求する姿勢を重視し,「トライボロジーに 立脚した機械設計一Tribologically-based Machine Design一」を合言葉に研究活動を行っています.

\section{2. 研究室のメンバーとモットー}

2009 年 11 月時点において本研究室は, スタッフ 1 名, ポスドク 1 名, 大学院博士後期課程 1 名, 前期課程 12 名, 学部 4 名, 短期留学生 1 名の総勢 20 名で構成されていま す，広範な「知識」を身に付け，それらにもとづく多面的 かつ論理的な「思考」を磨き，各人の有する潜在能力を引 き出すためにも, 海外からの共同研究者の短期滞在, 外部 機関研究者のゼミへの参加（図 1), 共同研究者との定例 ミーティングや技術相談のための産官学からの研究者の来 研などオープンな交流を大切にしています。，そのような交 流や研究室内の数多くのイベントを通し, 和敬静寂の心を もち充実感, 達成感および満足感を共有できる「知と和に 満ちたチームづくり」を心がけています.

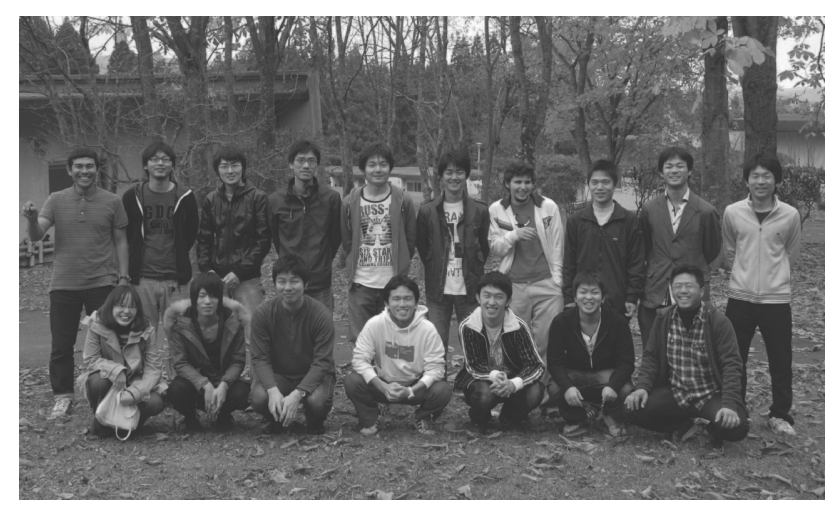

図 1 東北大学川渡共同セミナーセンターでの 2009 年秋ゼミ (2 名の外部機関からの参加者を含む)

\section{3. 研究内容の紹介}

表面と接触面の科学（ナノ・マイクロスケールでの構 造, 表面テクスチャ, 表面エネルギー, 摩擦化学反応, 摩 擦発熱, 摩擦帯電などの表面・インターフェースでの現象 解明), 摩擦と摩耗の制御技術（高機能表面・高機能イン ターフェースの創成技術）とそれらに基づく高度な機械シ ステムの創生を対象とした研究を行っています. トライボ ロジー特性は, システムの応答特性であることを深く理解 し, 機械システムの中で表面・インターフェースの機能を 考え, 表面・インターフェースの機能性をもとに機械シス テムを創ることを本研究室の基本コンセプトとしています (図2)，また，多くの研究テーマは，学内を含む産官学の 多くの共同研究者とともに遂行されており, 社会的ニーズ を常に念頭に, 多面的かつ論理的に「本質」を追求するこ とを心がけています。

現在取り組んでいる研究のいくつかを以下に紹介します.

3.1 摩擦駆動アクチュエータシステムの研究開発一表 面エネルギーと摩擦帯電の制御による耐摩耗のた めの表面・インターフェース創生と機械システム 設計の融合研究一

小型化, 軽量化, 簡素化, 高速化, 高精度化を可能にす る摩擦駆動型アクチュエータ（超音波モー夕抢よび弾性表 面波モー夕) を用いた駆動システムの開発を行っていま す。この実現には高摩擦と耐摩耗を両立する表面・インタ ーフェースが不可欠となりますが, これは摩擦材料や表面 性状の選定を意味するだけではありません．システムとし て表面とインターフェースを制御する設計が求められま す. 従来不可能であった精度の駆動システムを創生すべ く, 摩擦駆動部の摩耗形態制御, 摩耗粒子制御のための表 面エネルギーや摩擦带電を考慮したトライボロジーに立脚 した機械設計論の確立を目指しています（図 3)。

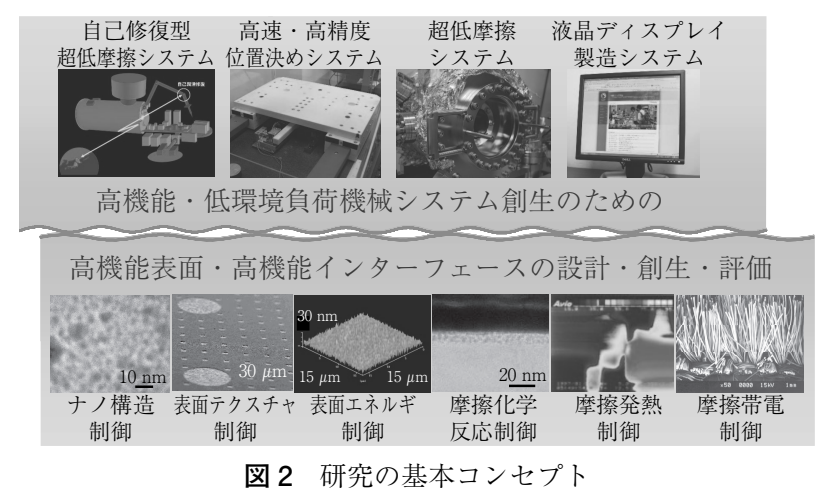

精密工学会誌 Vol.76, No.2, 2010

171 

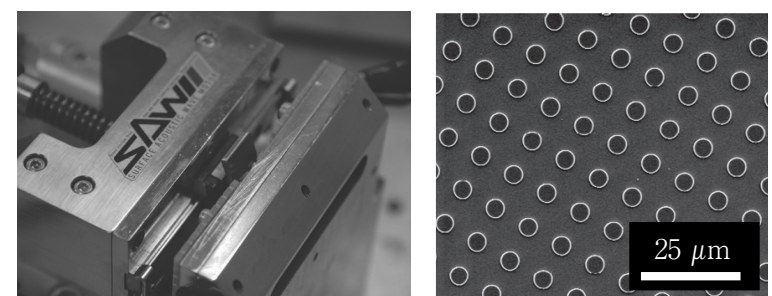

図 3 弾性表面波を用いた摩擦駆動システムと表面エネルギーを制 御した機能表面の一例

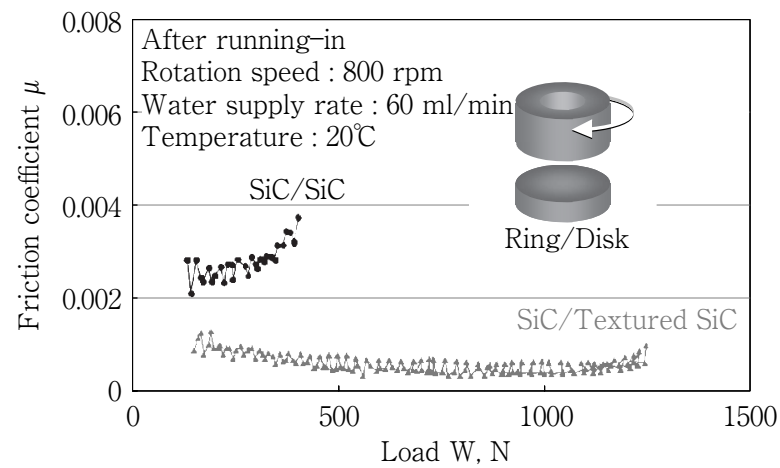

図 4 表面テクスチャとなじみ制御による水中に打ける炭化ケイ素 同士の摩擦特性の大幅な改善

\section{2 低環境負荷機械のための低摩擦システムの研究開 発一表面テクスチャとなじみの制御による低摩擦 のための表面・インターフェース創生一}

油を潤滑剂としてしゅう動される金属と比較し，七ラミ ックスは水を潤滑剤として非常に低い摩擦を与えることが できます。この特性は，表面テクスチャとなじみの制御に より格段に改善され，非常に高い許容荷重を有するととも に摩擦倸数 0.0005 の極めて低い摩擦を発生させることも可 能となります（図 4)。現在は，低摩擦発現のための表面テ クスチャ設計論の確立となじみ現象の解明により，低環境 負荷機械としての潤滑システムの実現を目指しています.

\section{3 ナノテクノロジーのための低摩擦システムの研究} 開発一摩擦化学反応制御による低摩擦のための表 面・インターフェース創生一

窒化炭素膜に不活性ガスを吸着させることにより無潤滑 状態にもかかわらず油潤滑と同等の摩擦係数 0.003 の低摩 擦を発生させることができます。これは従来の潤滑法の使 用が困難なマイクロマシンをはじめとする小型機器の潤滑 法として大いに期待されます。摩擦に伴うナノオーダの摩 擦表面層の形成（図 5) が, この低摩擦発現の鍵を握るこ とが明らかになってきました。現在は，低摩擦発現のため の摩擦表面層の形成機構の解明とそれに基く炭素系硬質薄 膜の成膜技術ならびに摩擦表面層のアクティブ制御技術の 確立により，ナノテクノロジーを支える潤滑技術の実現を 目指しています。

\section{4 真空機器のための低摩擦システムの研究開発}

一ナノ構造制御による低摩擦のための表面・インターフ エース創生一

ナノサイズの固体潤滑剂を硬質な母材に分散させた構造

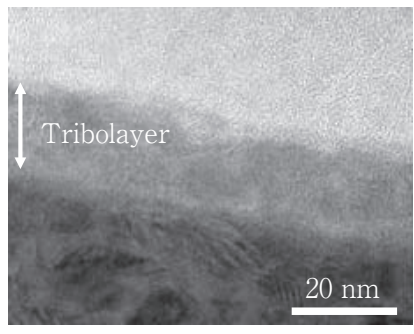

図 5 低摩擦発現の鍵を握るナノ 摩擦表面層

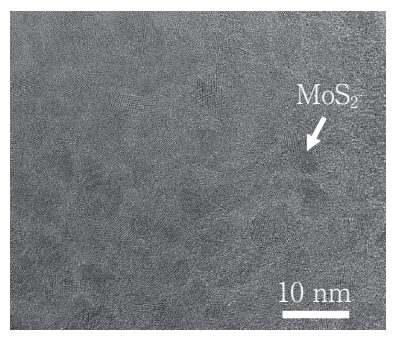

図6 低摩擦を実現するナノ $\mathrm{MoS}_{2}$ 含有 DLC

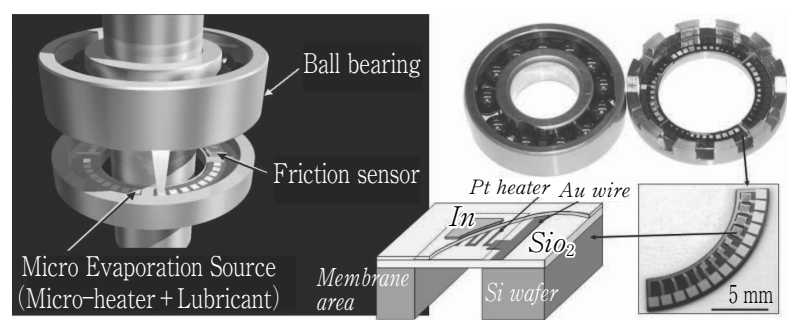

図 7 マイクロ蒸着源とそれを用いたトライボコーティング法によ る自己修復潤滑システムの概念図

体は分散させた固体潤滑剤単体より低い摩擦を与えること ができます。これは，当研究室が実験的に明らかにした事 実です。この知見をもとに現在，ダイヤモンドライクカー ボンを母材にナノサイズの固体潤滑剂を分散させた新しい 被膜の創生（図 6）と真空環境に掞ける低摩擦システムへ の応用に関する研究を行っています。ナノサイズの固体潤 滑剤が分散した構造体の可能性をうまく引き出すためのシ ステム設計論の確立により, 真空環境下の安心安全な低摩 擦システムの実現を目指しています。

\section{5 静肃な医療機器システムの研究開発一高機能表 面・インターフェースの長期維持システム創生一}

静肃で被験者に安心を与える医療機器の実現を目指し, 従来の固体潤滑剤では達成し得ない低摩擦と低振動を半永 久に持続できる「自己修復潤滑システム (図 7)」の研究 開発を行っています. 現在は, 低摩擦の長期維持を可能に する潤滑膜形成機構の解明と自己修復システムの設計論の 確立により, 高機能機械機器の象徵となりえる潤滑特性の 自己修復技術の実現を目指しています。

\section{4.おわりに}

学際科学, 基盤技術として位置し, 科学と技術の両側面 を有し, 幅広い学問分野との接点を有するトライボロジー には，新しい技術を創生する鍵がたくさんあります，今後 も国内外の技術者, 研究者との深い交流とそれにより得ら れる幅広い知識と多面的, 論理的な考察を展開し, 独創的 な研究を進めるべく最大限の努力をしていきたく思ってお ります。

当研究室の活動にご関心をもたれる方がございました ら，是非ご一報いたければ幸甚です，最後にこれまで産官 学の皆様より頂戴しております多大なるご支援に心より感 謝申し上げます。 